\title{
SOME ASPECTS OF FOOD CONSERVATION BY REFRIGERATION
}

\author{
By Frank A. Horne, \\ President of the Merchants Ref rigerating Company, New York, and Chairman \\ of the Commission on Legislation of the American \\ Association of Refrigeration.
}

There has been a remarkable reversal of public opinion in the past three or four years regarding the place cold storage and refrigerating have occupied with regard to the high cost of living.

The people, quite generally, led by newspaper agitation, entertained the idea that cold storage facilities were used to artificially control markets and increase prices; that foods were carried for long periods of time, and that the process was detrimental to the public health. It was then that the politicians appeared and various legislative proposals were introduced to control and greatly restrict the cold storage industry. In consequence of this situation and in response to the demand of the business men, whose legitimate enterprises were being unjustly assailed, a series of investigations and hearings were held which demonstrated beyond doubt that the popular notion and newspaper sensational attacks were entirely unfounded and erroneous, and that the cold storage warehousemen performed a useful public function in conserving our perishable foods, preventing deterioration and waste, by affording a scientific method by which the great surplus production of the flush season could be wholesomely preserved for consumption when nature rested from her labors and scant provision issued for the insistent and regular needs of mankind.

Then, too, it became apparent that the cold storage process, by enlarging the markets from the immediate time of production to the longer period of the year's cycle, encouraged the farmer to increase his yield, by making profitable his venture and led him to further develop the increasing outlets for his products. Thus to provide a means by which the maximum production can be carried forward a few months to the lean months, is no less a boon and a conserving instrument than is the transporting railway which brings the distant native food to those climes which fail to produce the necessities and luxuries of a bountiful table. 
It is a significant fact and a tribute to the excellence of the service that until the extent of this means of preservation became known, the public believed that the out-of-season products they were using were of current production because of the quality and wholesomeness of the foods thus made available.

That was a wise maxim of Benjamin Franklin, that "A penny saved is a penny earned," and is applicable to the salvage of waste made possible by the use of refrigeration in all the processes of handling our perishable food products. In the old days before these modern facilities were made available, a period of flush production meant a glut in the market and large quantities of spoiled and utterly useless foods, which must be sent to the dumps and by reason of the losses, subsequent production was greatly curtailed. With cold storage at hand the contrary condition prevails with the possible elimination of waste where fully employed and stimulation of profitable production.

The extent of the facilities for the conservation of foods by refrigeration is indicated by the following figures from the Ice and Refrigeration Blue Book: In 1911 there were 860 public cold storage warehouses having about $169,541,000$ cubic feet of storage space and representing an investment of approximately $\$ 75,000,000$. It is estimated that the value of goods stored in one year ranges from $\$ 500,000,000$ to $\$ 700,000,000$. Notwithstanding these large figures, it is calculated that not over from 5 per cent to 10 per cent of the annual production of such foods as eggs, butter, poultry and meats are placed in cold storage.

It is not difficult to demonstrate the proposition that refrigeration and cold storage are great agents of conservation of our perishable foods, but it is pertinent to inquire whether the dangers and objections to cold storage, which have been mentioned, really exist or are sufficient to overcome the conservation function. It will be well to consider the answers which the experts and scientific investigators give to these questions as presented in their testimony at the hearings and the other official investigations which have been held.

The statement that the cold storage warehouses helped certain interests to control prices is refuted by the testimony before the United States Senate committee on manufactures that the warehousemen generally do not own the goods-that in 27 leading warehouses during 1910 there were 9,380 storers, and that in one New York establishment there were 1,442 owners of goods stored. 
That cold storage has had an injurious economic effect was further disproved by a study of average prices of butter and eggs by $\mathrm{Mr}$. F. G. Urner, editor of the New York Produce Review, in which the market values of these goods for a period of ten years before the advent of cold storage were compared with a like period subsequent to the general use of refrigerating warehouses. The result of this inquiry was presented before the committee on manufactures of the United States Senate and appears on page 137 of their hearings. Mr. Urner's conclusions may be summarized as follows: "The per capita consumption of eggs at New York has increased largely since ample cold storage facilities became available." Also he says: "The average price of fresh gathered and storage eggs taken together were lower during the season of scarcity since cold storage has been available than were the prices for fresh gathered eggs before cold storage was available, notwithstanding a well known advance in the prices of nearly all commodities."

The Massachusetts commission on cold storage has this to say as to the effect of cold storage on increased production and price:

"The per capita receipts of the chief food products subject to cold storage handling, namely, eggs, butter and poultry, increased greatly in Boston and New York markets during the decade 1901-10, as compared with the decade 1881-90, prior to the general adoption of cold storage methods. This fact appears to indicate that cold storage has contributed to increase the volume of production." Again this report says: "The average prices of butter and poultry were lower in the second decade than in the first; the average price of eggs was slightly higher, but this fact is explained by peculiar conditions affecting the egg market."

With respect to the alleged injurious effect of cold storage on health, there is an abundance of scientific testimony to the contrary. On this phase of the subject the Massachusetts commission declared itself as follows: "Instead of being a menace to the public health, cold storage has, in the main, exhibited itself as a great agency for the conservation of the vital resources of the population. It has enlarged, diversified and enriched the food supply of the people. Without cold storage the crowded masses in the urban centers would be obliged to subsist on a dietary at once more meagre and more costly than that enjoyed at the present time."

There is much testimony of experts with regard to the whole- 
someness of cold storage foods. The following may be mentioned as eminent advocates: Hon. James Wilson, ex-secretary of agriculture; Dr. H. W. Wiley, Prof. William. T. Sedgwick, of the Massachusetts Institute of Technology, Dr. Wm. J. Gies, professor of biological chemistry, and Dr. M. E. Pennington, chief of food research laboratory, United States Department of Agriculture.

The latter testified before the Senate committee that, in reference to poultry, "There would probably be a greater change in twentyfour hours if the temperature was from $65^{\circ}$ to $75^{\circ} \mathrm{F}$., than if the temperature was $10^{\circ} \mathrm{F}$. for twelve months." Thus clearly indicating that waste, deterioration and loss occur through absence of refrigeration in the handling of these products rather than in period storage.

The common notion that goods are generally held for very long periods in cold storage is disproved by the report of the secretary of agriculture last year, showing the following average periods of storage:

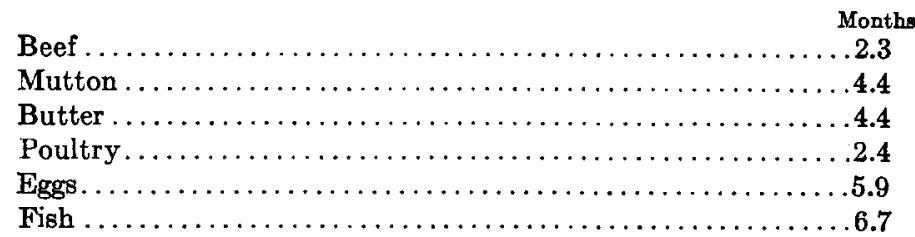

There has been no objection to proper and reasonable regulation such as supervisory inspection and publicity of holdings, and the fact that cold storage warehouses continue to thrive in spite of the crudities and burdensome features of some of the provisions of the cold storage laws, which have been enacted in several states, is a demonstration that cold storage preservation is a vital and valuable public utility and a vast agency of conservation in respect to the food products of the people. 